\title{
Socioeconomic Characteristics, Nutritional Status, Health Status, and Quality of Life among Tea Plantation Workers in Pangalengan, West Java, Indonesia
}

\author{
Amalina Ratih Puspa ${ }^{1 *}$, Faisal Anwar ${ }^{2}$, Ali Khomsan ${ }^{2}$ \\ ${ }^{1}$ Nutrition Department, Faculty of Science and Technology, Universitas Al Azhar Indonesia, \\ South Jakarta 12110, Indonesia \\ ${ }^{2}$ Department of Community Nutrition, Faculty of Human Ecology, IPB University, Bogor 16680, Indonesia
}

\begin{abstract}
This cross-sectional study aimed to analyze the association between socioeconomic characteristics, nutritional status, anemia status and health status with the quality of life of tea pickers in Pangalengan, West Java, Indonesia. Subjects were 116 women of childbearing age (15-49) years. Anemia status data (hemoglobin levels) were taken using HemoCue $\mathrm{Hb} 201+$, while nutritional status data were collected through anthropometric measurements (weight and height). Quality of life data was collected using the Short Form-36 (SF-36) questionnaire consisting of the Physical Component Summary (PCS) score and Mental Component Summary (MCS) score. PCS consists of physical function, physical role, pain, and general health dimensions. MCS consists of vitality, social functions, the role of emotions, and mental health. Data were analyzed using a Spearman correlation test, Pearson correlation test, and logistic regression test. The results showed that there was no significant relationship between anemia status and nutritional status with quality of life ( $\mathrm{p}>0.05)$. However, non-anemic subjects tend to have higher PCS and MCS scores than anemic subjects. There was a positive relationship between Acute Respiratory Infection (ARI) with MCS in terms of social function dimensions, and joint pain with MCS in the emotional role dimension $(p<0.05)$. The variables related to the quality of life were the number of family members and expenditures. Subjects with large family size ( $\geq 4$ people) had a 3.5 times risk for experiencing lower quality of life compared with subjects with smaller family $(<4$ people) $(\mathrm{OR}=3.52$; 95\% CI:1.23-10.05). Subjects with monthly expense of $>$ Rp. 343,646 had lower risk of experiencing low quality of life $59.7 \%$ compared to subjects who had household an expense of $<$ Rp. 343,646 (OR=0.403; $95 \%$ CI:0.17-0.96).
\end{abstract}

Keywords: anemia, health status, nutritional status, quality of life, tea picker

\section{INTRODUCTION}

More than $30 \%$ of the world's population is anemic, but anemia is a difficult nutritional problem to solve. Most anemia is caused by iron deficiency and, in some areas, is exacerbated by the presence of infectious diseases (WHO 2008). The prevalence of anemia in Indonesia has not shown any significant decrease. The national Basic Health Research (Riskesdas) 2013 data shows the prevalence of anemia in women of childbearing age, was categorized as mild to moderate category of public health problem, which is 18.4-20.1\% (Balitbangkes 2013).

Women of childbearing age are prone to experience iron deficiency anemia Iron Deficiency Anemia (IDA). During this reproductive age, iron deficiency and anemia can reduce work capacity or maximal aerobic capacity (VO2 max) and also cause a decrease in work productivity through decreased oxygen supply to the tissues (Haas \& Brownlie 2001). The main symptom of anemia is fatigue. These symptoms can develop into other problems such as dizziness, depression, cognitive impairment, and others. The symptoms experienced often affect the quality of relationship and social roles due to lack of energy and interest in socializing (Cella \& Breitbart 2001). In addition, there is a strong relationship between fatigue with physical health dimensions and emotional roles in the quality of life that can limit the subject at work or in daily activities (Efficace et al. 2016).

According to Fayers and Machin (2007), quality of life is a component of happiness and satisfaction with life. The definition of quality of

\footnotetext{
"Corresponding Author: tel: +62 2172792753, email: amalina.puspa@uai.ac.id
} 
life is often of a different meaning in each person because it has many influencing factors such as finance, safety, and health. For this reason, a term of quality of life-related to health is used in the field of health. The definition of health, according to the World Health Agency (WHO), is a state of well-being that includes physical, mental, and social, which is not only free from disease or disability. This means that the quality of human life related to health covers not only physical health, but also includes mental, social, and emotional health (Niswah 2014).

Health-related quality of life can decrease due to reduced functional abilities such as the ability to work, social interaction, recreational activities, and the decline in the meaning of subjective well-being (Flechtner \& Bottomley 2003). Also, quality of life is affected by one's health status. Research by Zubaran et al. 2008 in 120 subjects in Brazil showed that there was a significant relationship between health status and quality of life. Health-related quality of life is also influenced by a person's nutritional status. Poor nutritional status can reduce physiological function, increase the risk of disease complications, and even death, which can result in decreased quality of life (Wanden-Berghe et al. 2009; Pearson et al. 2001).

Tea pickers are often the choice of work for women in rural areas. This is due to limited employment in rural areas, lack of skills, and low education (Kusumawati 2012). Tea pickers often find it challenging to obtain a healthy and proper settlement environment that affects the nutritional and health status, which can trigger various diseases (Fitriyani et al. 2008). This study aims to analyze the association between socioeconomic characteristics, nutritional status, anemia status, health status, with quality of life of tea pickers in Nusantara Plantation Company VIII (PTPN VIII) Pangalengan, West Java.

\section{METHOD}

\section{Design, location, and time}

The design of this study was crosssectional. The research location was determined purposively, it was at the Nusantara Plantation Company VIII (PTPN VIII) located in Pangalengan, West Java, Indonesia. There are four selected gardens, namely Malabar Gardens, Purbasari Gardens, Sedep Gardens, and Talun
Santosa Gardens. The study was conducted in April-July 2016. This research is part of a larger study entitled "Income Contribution, Food Consumption, Iron Deficiency Anemia among Women Workers in Tea Plantation and the Effect of Multinutrients Supplementation with Nutrition Education to Increase Their Productivity " chaired by Faisal Anwar.

\section{Sampling}

Subjects in this study were tea pickers. Inclusion criteria in the selection of subjects were women of childbearing age 15-49 years old, married/never married, not pregnant and/or breastfeeding, and were willing to participate in this study by filling out the informed consent. The minimum number of subjects was 116 people. This amount was obtained based on the formula from Lemeshow et al. (1997) by using the prevalence of anemia in women of childbearing age in West Java of $13.4 \%$ (BPPK Depkes RI 2008 ), the total population of 250 , and the degree of trust of 5\%. This research has received ethical approval from Diponegoro University No. 22/ EC / FKM / 2015.

\section{Data collection}

The type of data collected is primary and secondary data. The data in this study are baseline data from the leading research. Primary data include Haemoglobin $(\mathrm{Hb})$ level, socioeconomic characteristics (age, marital status, household size, recent education, household expenses), health status, nutritional status (anthropometry and anemia status), and quality of life. Blood drawn for the $\mathrm{Hb}$ test did not require the subject to fast, the blood samples were analyzed using HemoCue $\mathrm{Hb}$ 201+. Data on subject characteristics and health status were obtained through interviews using a questionnaire. Quality of life data was collected through interviews with the Short Form-36 (SF-36) questionnaire consisting of the Physical Component Summary (PCS) and Mental Component Summary (MCS). PCS consists of physical function, physical role, pain, and general health dimensions. MCS consists of vitality, social functions, the role of emotions, and mental health. The SF-36 used has been translated and tested to have good internal consistency with an alpha coefficient $\geq 0.70$ (Rachmawati et al. 2014). 


\section{Data analysis}

The data was processed and analyzed using Microsoft Excel 2013 software and SPSS version 16.0. Subjects were categorized to be anemic if the $\mathrm{Hb}$ concentration was $<12.0 \mathrm{~g} / \mathrm{dl}$. The calculation of nutritional adequacy level is calculated according to nutritional adequacy recommended by the Ministry of Health of the Republic of Indonesia (MoHRI 2013). The nutritional status classified as underweight (BMI $<18.5 \mathrm{~kg} / \mathrm{m}^{2}$ ), normal (BMI 18.5-24.9 kg/m²), overweight (25.0-26.9 kg/m ${ }^{2}$ ), and obese (BMI> $\left.27 \mathrm{~kg} / \mathrm{m}^{2}\right)$. Health status data consists of a history of illnesses and health conditions within the past four weeks.

Questions contained in the SF-36 questionnaire (RAND 2009) were related to the subject's general perception of their health at the point of interview compared to four weeks ago. The SF-36 questionnaire consisted of 36 questions representing eight dimensions namely physical function (10 questions), physical role (4 questions), pain (2 questions), general health (5 questions), social function (2 questions), vitality ( 4 questions), the role of emotions (3 questions), and mental health (5 questions). Quality of life is categorized based on the average quality of life score. Subjects had a good quality of life if the score $\geq 74$ and less if the score $<74$. The bivariate analysis uses the Pearson correlation test if the data is normally distributed and the Spearman Rank correlation test if the data is not normally distributed. To analyze factors affecting the quality of life, logistic regression analysis was used. The variables included in the logistic regression analysis were the variables which in the bivariate analysis have $p<0.25$. The results were said to be statistically significant when $\mathrm{p}<0.05$.

\section{RESULTS AND DISCUSSION}

\section{Socioeconomic characteristics}

Table 1 shows that the mean age of the subjects was $41.7 \pm 5.5$ years. More than half of the subjects $(67.2 \%)$ were middle aged (41 to 60 years). According to Leslie \& Hankey (2015), the amount of energy needed by the body will increase with age and reach its peak in adulthood, then the amount of energy needed by the body will decrease again afterward. In addition to decresing energy need, towards the age of 45 years, there will also be a decrease in work capacity, which includes functional, mental, and social capacity (McPhee et al. 2016 ).

Most subjects completed the elementary school level education (57.8\%). According to Pradono and Sulistyowati (2014), low levels of education will affect the low ability to develop effective life capacities, which will ultimately affect the ability and skills to work, access to health facilities, welfare, and social support.

Almost all subjects had a small number of family members, less than four people $(74.1 \%)$. The family size largely determines the family needs. More family members mean more resources are needed to meet the family needs (Erwin \& Karmini 2012). The average expenditure per capita of the subjects was Rp. 626,958 \pm Rp. 312,655. Most subjects were classified as not poor (82.8\%). Almost all subjects were married $(94.0 \%)$.

Table 1. Distribution of subject characteristics

\begin{tabular}{|c|c|c|}
\hline Characteristics & $\mathrm{n}$ & $\%$ \\
\hline \multicolumn{3}{|l|}{ Age (years) } \\
\hline Young adults $(18-40)$ & 38 & 32.8 \\
\hline Middle adulthood (41-60) & 78 & 67.2 \\
\hline Average \pm SD & \multicolumn{2}{|c|}{$41.7 \pm 5.5$} \\
\hline \multicolumn{3}{|l|}{ Education } \\
\hline No school & 1 & 0.9 \\
\hline Not completed in elementary school & 35 & 30.1 \\
\hline Elementary school/equivalent & 67 & 57.8 \\
\hline Junior high school/equivalent & 12 & 10.3 \\
\hline High school/equivalent & 1 & 0.9 \\
\hline \multicolumn{3}{|l|}{ Number of family members (people) } \\
\hline A small family $(\leq 4)$ & 86 & 74.1 \\
\hline Medium family ( 5-6 ) & 27 & 23.3 \\
\hline Large family $(\geq 7$ ) & 3 & 2.6 \\
\hline \multicolumn{3}{|l|}{ Expenditures per capita } \\
\hline Poor $(<$ Rp. 344,000$)$ & 20 & 17.2 \\
\hline Not poor $(\geq$ Rp. 344,000) & 96 & 82.8 \\
\hline Average \pm SD & \multicolumn{2}{|c|}{$626,958 \pm 312,655$} \\
\hline \multicolumn{3}{|l|}{ Marital status } \\
\hline Married & 109 & 94.0 \\
\hline Divorced & 7 & 6.0 \\
\hline
\end{tabular}


Nutritional status. Nutritional status was assessed through anthropometric methods (Body Mass Index) and biochemistry (hemoglobin levels). Table 2 shows that $44.0 \%$ of the subjects were classified as having normal nutritional status, but $53.4 \%$ of the subjects were classified as overweight and obese. The prevalence of subjects who had a BMI $>25$ in this study was greater than the Riskesdas data (2013), which was $32.9 \%$ and the research of Mahardikawati et al. (2008) on tea pickers in Pangalengan which was $30.4 \%$. Good nutritional status is needed by tea pickers to be able to improve performance and productivity; this is mainly due to the work of tea pickers relying heavily on physical fitness (Kundu et al. 2013).

Anemia is a condition when the body lacks in red blood cells, or the concentration of hemoglobin in the blood is insufficient so that there is a disruption in transporting oxygen throughout the body (Balitbangkes 2013). Table 2 shows that the prevalence of anemia was $28.5 \%$. The average hemoglobin level was $12.6 \mathrm{~g} / \mathrm{dl}$, with the lowest level was $9.1 \mathrm{~g} / \mathrm{dl}$, and the highest was $14.8 \mathrm{~g} / \mathrm{dl}$. The prevalence of anemia in this study is greater than the prevalence of anemia in women in Indonesia, which is $23.9 \%$. Iron deficiency and anemia can reduce work capacity and productivity through decreased oxygen supply to tissues (Haas \& Brownlie 2001).

Health status. Health status is a description of the history of the disease suffered by the subject at the point of interview and the subject's health condition in the last four weeks. Health is a basic right of every human being and is one of the factors that determine the quality of human resources. Table 2 shows that most of the subjects complained about Acute Respiratory Infections (ARI) $(81.9 \%)$ and joint pain $(73.3 \%)$ at the point of interview. Tea pickers work by collecting tea using a container that is carried on the back. The tea loads that reach about $40-75 \mathrm{~kg} /$ day on their back ca uses muscle tension and discomfort. Meanwhile, for the history of illness the majority $(83.6 \%)$ of subjects had suffered from various health complaints and the most common was ARI (39.2\%). Health complaints experienced by the subject can hamper work productivity (Agung 2008).

Quality of life. According to Fayers and Machin (2007), quality of life is a component of happiness and satisfaction with life. The definition
Table 2. Distribution of subjects based on nutritional status and health status

\begin{tabular}{|c|c|c|}
\hline Nutritional status & $\mathrm{n}$ & $\%$ \\
\hline \multicolumn{3}{|l|}{ Body Mass Index $\left(\mathrm{kg} / \mathrm{m}^{2}\right)$} \\
\hline Thin $(<18.5)$ & 3 & 2.6 \\
\hline Normal (18.5-24.9) & 51 & 44.0 \\
\hline More (25-26.9) & 20 & 17.2 \\
\hline Obesity $(\geq 27)$ & 42 & 36.2 \\
\hline Average \pm SD & \multicolumn{2}{|c|}{$25.8 \pm 3.8$} \\
\hline Non anemia $(\mathrm{Hb}>12 \mathrm{~g} / \mathrm{dl})$ & 83 & 71.5 \\
\hline \multicolumn{3}{|l|}{ Anemia } \\
\hline Mild (Hb 11.0-11.9 g/dl) & 24 & 20.7 \\
\hline Moderate $(\mathrm{Hb} 8.0-10.9 \mathrm{~g} / \mathrm{dl})$ & 9 & 7.8 \\
\hline Average $\mathrm{Hb} \pm \mathrm{SD}(\mathrm{g} / \mathrm{dl})$ & \multicolumn{2}{|c|}{$12.6 \pm 1.1$} \\
\hline Health status & $\mathrm{n}$ & $\%$ \\
\hline \multicolumn{3}{|l|}{ Infectious Disease } \\
\hline Tuberculosis & 3 & 2.5 \\
\hline ARI* (cough, runny nose) $^{*}$ & 95 & 81.9 \\
\hline Helminthiasis & 6 & 5.2 \\
\hline \multicolumn{3}{|l|}{ Non-communicable diseases } \\
\hline Joint pain & 85 & 73.3 \\
\hline Hypertension & 46 & 40.0 \\
\hline Uric acid & 46 & 40.0 \\
\hline
\end{tabular}

History of health conditions for the past four weeks

\begin{tabular}{lcc} 
Pain free & 19 & 16.4 \\
Sickness & 97 & 83.6 \\
ARI (cough, cold) & 38 & 39.2 \\
Fever & 3 & 3.1 \\
Hypertension & 3 & 3.1 \\
Stomach pain & 13 & 13.4 \\
Joint pain & 12 & 12.4 \\
Headache & 14 & 14.4 \\
Etc & 14 & 14.4 \\
\hline
\end{tabular}

ARI: Acute Respiratory Infections

of quality of life is often of a different meaning for each person because it has many influencing factors such as finance, safety, and health. For this reason, a term of quality of life-related to health is used in the field of health. Assessment of quality of life is not only influenced by physical conditions, but also by mental, social and emotional states so that it can be seen as a multidimensional concept consisting of three main areas namely physical, psychological (cognitive and emotional), and social (Loonen et al. 2001). Assessment of quality of life provides new insights in the assessment of long-term outcomes 
based on the definition of health, according to the World Health Organization (WHO), which is physically, mentally, and socially healthy, not only free from disease or weakness. Assessment of the quality of life of the subjects in this study was carried out using a standardized Short Form 36 (SF-36) questionnaire. Quality of life in this study consists of eight dimensions, namely physical function, physical role, emotional role, vitality, mental health, social function, pain, and general health. Also, quality of life is divided into two major components, namely the Physical Component Summary (PCS) and the Mental Component Summary (MCS). Table 3 shows that the average score of the highest quality of life of subjects was in the dimensions of physical function (88.8 \pm 17.2 ), and the lowest was in the dimension of pain (62.1 \pm 22.9$)$. Meanwhile, the average PCS subject score was $70.4 \pm 18.0$, and MCS was $78.0 \pm 15.2$. Table 3 also shows that more than half of the subjects had a relatively good quality of life $(62.1 \%)$, and only $37.9 \%$ of the subjects classified as having a poor quality of life.

Table 3. The average score of quality of life of the subjects by dimensions and the distribution of subjects by the quality of life categories

\begin{tabular}{lcc}
\hline \multicolumn{1}{c}{ Dimension } & Average & $\begin{array}{c}\text { Elementary } \\
\text { school }\end{array}$ \\
\hline Physical function & 88.8 & 17.2 \\
Physical role & 66.4 & 44.1 \\
The role of emotion & 81.9 & 36.4 \\
Vitality / energy & 69.5 & 13.5 \\
Mental health & 74.7 & 14.5 \\
Social function & 86.0 & 18.7 \\
Pain & 62.1 & 22.9 \\
General health & 64.2 & 10.9 \\
PCS & 70.4 & 18.0 \\
MCS & 78.0 & 15.2 \\
\hline \multicolumn{1}{c}{ Quality of life category } & $\mathrm{n}$ & $\%$ \\
\hline Good (scores $\geq 74)$ & 72 & 62.1 \\
Poor (score $<74)$ & 44 & 37.9 \\
Average \pm SD & \multicolumn{2}{c}{$74.2 \pm 14.7$} \\
\hline PCS: Physical Component Summary; MCS: Mental Com- \\
ponent Summary & &
\end{tabular}

\section{Socioeconomic characteristics and the} quality of life. Table 4 shows that there was no relationship between age, education level, marital status, and subject expenditure with physical components (PCS) and mental components of quality of life (MCS) $(\mathrm{p}>0.05)$. This result is in line with the study of Al-Aboudi et al. (2015), which shows that there was no significant relationship between age, education level, and health-related quality of life. However, the results of Bjorner's research (2013) on 3,445 adult subjects in Massachusetts, Illinois, and California showed a different thing that there was a strong relationship between high quality of life scores with younger subject's age, marital status, and education level. Table 4 also shows that there was a relationship between the number of family members and the PCS score $(\mathrm{p}=0.003, \mathrm{r}=0.277)$. The greater the number of family members, the better the quality of life score of the subject based on the dimensions of physical role and PCS. This means that the greater number of family members does not reduce the amount of time and limit the subject to work/activities related to the physical.

\section{Nutritional status and quality of life}

The eight dimensions of quality of life related to health can be concluded into two parts,

Table 4. Relationship of subject's socioeconomic characteristics with quality of life dimensions

\begin{tabular}{|c|c|c|c|}
\hline \multirow{2}{*}{ Characteristics } & \multirow{2}{*}{$\begin{array}{l}\text { Correlation } \\
\text { coefficient }\end{array}$} & \multicolumn{2}{|c|}{ Quality of life } \\
\hline & & $\mathrm{PCS}^{3)}$ & $\mathrm{MCS}^{4)}$ \\
\hline \multirow{2}{*}{ Age } & $\mathrm{r}$ & 0.084 & -0.011 \\
\hline & $\mathrm{p}^{1)}$ & 0.372 & 0903 \\
\hline \multirow{2}{*}{$\begin{array}{l}\text { A long time of } \\
\text { school }\end{array}$} & $\mathrm{r}$ & -0.049 & -0.119 \\
\hline & $\mathrm{p}^{1)}$ & 0601 & 0.203 \\
\hline \multirow{2}{*}{ Marital status } & $\mathrm{r}$ & -0.122 & $-0,077$ \\
\hline & $\mathrm{p}^{2)}$ & 0.193 & 0.413 \\
\hline \multirow{2}{*}{ Spending } & $\mathrm{r}$ & 0.135 & 0.11 \\
\hline & $\mathrm{p}^{1)}$ & 0.149 & 0.238 \\
\hline \multirow{2}{*}{$\begin{array}{l}\text { Number of family } \\
\text { members }\end{array}$} & $\mathrm{r}$ & 0.277 & -0.018 \\
\hline & $\mathrm{p}^{1)}$ & $0.003^{*}$ & 0.847 \\
\hline
\end{tabular}


namely Physical Component Summary (PCS) and Mental Component Summary (MCS). PCS consists of dimensions of physical function, physical role, pain, and general health. MCS consists of vitality, social functions, the role of emotions, and mental health. The nutritional status of the subjects was assessed based on body mass index and hemoglobin levels. Table 5 shows that the average PCS scores in the nutritional status of thin, normal, overweight, and obesity were $71.9 \pm 21.3, \quad 68.5 \pm 19.6, \quad 75.0 \pm 12.7, \quad 70.6 \pm 18.1$, respectively. The highest average PCS scores were in subjects with overweight nutritional status, and the lowest was in subjects with normal BMI. These results are in line with the study of Ul-Haq et al. (2012), which showed that quality of life scores improved in overweight subjects, but decreased in obese subjects. Research Brown et al. (2000) in Australia show different things. Subjects who had a normal BMI $\left(18.5-25 \mathrm{~kg} / \mathrm{m}^{2}\right.$ ) has the highest scoring average for the domains of physical functioning, general health, and vitality on the SF-36 questionnaire. According to Brown et al. (2000), women of childbearing age who have excess BMI tend to have more health complaints such as hypertension, asthma, headaches, back pain that can affect the subject's decreased perception of the quality of life. This difference in results is thought to be caused because, in this study, half of the subjects who had a normal BMI had anemia (45.5\%) and were ill in the last four weeks $(42.3 \%)$.

Table 5 shows that the mean MCS scores on thin, normal, excessive, and obese nutritional status were $67.2 \pm 11.4,79.4 \pm 14.4,77.2 \pm 14.8$, $77.5 \pm 16.5$. The highest average MCS score is

Table 5. Average nutritional status scores based on the quality of life

\begin{tabular}{lcc}
\hline \multirow{2}{*}{ Nutritional status } & \multicolumn{2}{c}{ Quality of life } \\
\cline { 2 - 3 } Thin & PCS $^{*}$ & MCS $^{*}$ \\
Normal & $71.9 \pm 21.3$ & $67.2 \pm 11.4$ \\
Overweight & $68.5 \pm 19.6$ & $79.4 \pm 14.4$ \\
Obesity & $75.0 \pm 12.7$ & $77.2 \pm 14.8$ \\
\hline
\end{tabular}

${ }^{*}$ PCS: Physical Component Summary; ${ }^{*}$ MCS: Mental Component Summary in normal nutritional status, and the lowest is in subjects with underweight nutritional status. These results are in line with the research of Wee et al. (2010) on Asian ethnic subjects (Chinese, Malay, and Indian) in Singapore, which showed that subjects with lean BMI were associated with MCS scores that were lower by 1.3 points compared to other BMI. Research Huang et al. (2006) in Taiwan showed that subjects with both overweight and obese BMI had higher mental component scores compared to those with normal BMI. The increase in BMI is followed by increasing MCS scores can be explained by socio-cultural factors such as values, attitudes, beliefs, and people's perceptions of body weight. Eastern culture views being overweight as something normal, healthy, beautiful, and a symbol of prosperity and happiness. This research also shows subjects tend to only begin to realize the dangerous health consequences when the subjects are hugely overweight.

The Pearson correlation test showed that there was no relationship between body mass index (BMI) and the dimensions of quality of life $(p>0.05)$ (Table 6). This result is in line with the research of De Zwaan et al. (2009), which states that there is no relationship between BMI with quality of life-related to health. However, Ul-Haq et al. (2013) showed different results; namely, there was a relationship between BMI and quality of life-related to health where the subjects with higher BMI tend to have lower PCS and MCS scores.

Table 6 also shows that there is no relationship between anemia status and quality of life $(p>0.05)$ this presumably because hemoglobin

Table 6 . The relationship of nutritional status with quality of life

\begin{tabular}{|c|c|c|c|}
\hline \multirow{2}{*}{$\begin{array}{l}\text { Nutritional } \\
\text { status }\end{array}$} & \multirow{2}{*}{$\begin{array}{l}\text { Correlation } \\
\text { coefficient }\end{array}$} & \multicolumn{2}{|c|}{ Quality of life } \\
\hline & & PCS $^{*}$ & MCS $^{*}$ \\
\hline Body Mass & $r$ & 0.032 & -0.007 \\
\hline $\begin{array}{l}\text { Index } \\
\text { (BMI) }\end{array}$ & $\mathrm{p}^{1)}$ & 0.734 & 0.94 \\
\hline Anemia & $\mathrm{r}$ & 0.002 & 0.065 \\
\hline $\begin{array}{l}\text { Status } \\
(\mathrm{Hb})\end{array}$ & $\mathrm{p}^{1)}$ & 0.986 & 0.49 \\
\hline
\end{tabular}

1)Pearson correlation test; "PCS: Physical Component Summary; ${ }^{*}$ MCS: Mental Component Summary 
levels in anemia subjects are classified as mild to moderate $(8.0-11.9 \mathrm{~g} / \mathrm{dl})$. According to Beck et al. (2012), often, sufferers of mild to moderate anemia do not realize that they have anemia, so the subject tends to work as usual and does not interfere with the daily activities of the subject. Moreover, research by Locatelli and Del Vecchio (2014) showed that worsening scores on each dimension of quality of life in subjects with anemia was significant when their $\mathrm{Hb}$ was $<9.0 \mathrm{~g} /$ dl. Thus, subjects with mild to moderate anemia tend not to have significant clinical effects because the subjects have reached a more stable state. A more stable hemoglobin level will affect the subject's better perception of his/her quality of life.

\section{Health status and quality of life}

Table 7 shows that there was a significant relationship between health conditions in the past four weeks with PCS scores $(r=0.39 ; \mathrm{p}=0.001)$ and $\mathrm{MCS}(\mathrm{r}=0.229 ; \mathrm{p}=0.014)$. Most subjects in the last four weeks experienced health problems with symptoms including fever, cough, sore throat, coryza (runny nose), and shortness of breath. This might have been caused by the weather during the data collection, which was in the rainy season. In addition, the condition of most of the sick subjects also affects the MCS scores. This is possible because when suffering from Acute

Table 7. Relationship of health status with quality of life

\begin{tabular}{|c|c|c|c|}
\hline \multirow{2}{*}{ Health status } & \multirow{2}{*}{$\begin{array}{l}\text { Correlation } \\
\text { coefficient }\end{array}$} & \multicolumn{2}{|c|}{ Quality of life } \\
\hline & & $\mathrm{PCS}^{1)}$ & $\mathrm{MCS}^{2)}$ \\
\hline \multirow{2}{*}{$\begin{array}{l}\text { Acute } \\
\text { Respiratory } \\
\text { Infection (ARI) }\end{array}$} & $\mathrm{r}$ & -0.118 & -0.059 \\
\hline & $\mathrm{p}$ & 0.209 & 0.527 \\
\hline \multirow{2}{*}{ Joint pain } & $\mathrm{r}$ & -0.054 & -0.121 \\
\hline & $\mathrm{p}$ & 0.563 & 0.197 \\
\hline \multirow{2}{*}{$\begin{array}{l}\text { Health } \\
\text { conditions for the } \\
\text { past } 4 \text { weeks }\end{array}$} & $\mathrm{r}$ & 0.309 & 0.229 \\
\hline & $\mathrm{p}$ & $0.001^{*}$ & $0.014^{*}$ \\
\hline $\begin{array}{l}{ }^{*} \text { The Spearman Rank } \\
\text { to } \mathrm{p}<0.05 \\
{ }^{1)} \mathrm{PCS} \text { : Physical Comp } \\
\text { Component Summary }\end{array}$ & $\begin{array}{l}\text { rrelation test } \\
\text { nent Summary }\end{array}$ & signific & $\begin{array}{l}\text { tly relatec } \\
\text { ental }\end{array}$ \\
\hline
\end{tabular}

Respiratory Infections (ARI), subjects tend to limit social activities such as visiting relatives, neighbors, studying, and social gatherings to prevent disease transmission thus increases the feeling of isolation.

The results of this study are in line with the study of Linder and Singer (2003) which showed that subjects who experience symptoms of fever, cough, sore throat, coryza (colds), and shortness of breath tend to experience a significant decrease in quality of life scores $(p<0.001)$. The decrease in quality of life scores in this study not only on the PCS scores (Dimension of physical function, physical role, body pain, and vitality), but there is also on the MCS scores (Dimension of social function, and mental health) (Linder \& Singer 2003).

\section{Factors affecting the quality of life}

The results of the multiple logistic regression test showed that the variables that affect the subject's quality of life were the number of family members and subjects' expenditures (Table 8). Subjects who have a large number of family members ( $\geq 4$ people) are had 3.5 times higher risk to experience lower quality of life compared to subjects who have small families $(<4$ people) $(\mathrm{OR}=3.52 ; 95 \%$ CI:1.23-10.05). The small number of family member enables family to increase social status. Families increasingly have the chance to send their children to higher education, increased health status, and more excellent savings opportunities so that it will have an impact on the quality of life that is increasing. Research by Santos et al. (2016) also showed that workers who lived with more than four people were associated with a lower quality of life. A large number of family members allow a person to be overloaded with work, which can affect health.

Table 8 shows that subjects with monthly expense of $>$ Rp. 343,646 had lower risk of experiencing low quality of life $59.7 \%$ compared to subjects who had household an expense of

Table 8. Logistic regression analysis of subjects' quality of life

\begin{tabular}{lccc}
\hline \multicolumn{1}{c}{ Variable } & $\mathrm{p}$ & $\mathrm{OR}$ & $95 \% \mathrm{CI}$ \\
\hline $\begin{array}{l}\text { Number of family } \\
\text { members }\end{array}$ & 0.019 & 3,521 & $1,233-10,052$ \\
Total expenditure & 0.041 & 0.403 & $0.168-0.964$ \\
\hline
\end{tabular}


$<$ Rp. 343,646 (OR=0.403; 95\% CI:0.17-0.96). The result implies that higher income has led to lower risk of deteriorating quality of life. However, the size of income alone is not enough to determine health status and quality of life of the household. According to Sulistyowati et al. (2017), the composition of household expenditure can be used as a measure to assess the level of the economic welfare of the community, the higher the percentage of expenditure for food against total expenditure, the lower the welfare of the community. This study found the proportion of the household expenditures were as follow (1) basic food (15.8\%), (2) cigarettes (12.7\%), (3) education $(9.7 \%)$, (4) snacks $(11.9 \%),(5)$ installments/credit (8.5\%), and (6) health (3.2\%).

We found the expenditure for cigarettes in our survey was almost the same to the proportion of income allocate for food. According to Semba (2006), poor household heads who smoke reached $73.8 \%$, and spending on tobacco reach $22 \%$ per capita per week of total the household expenditure. Increased household expenditure to buy cigarettes has strained the ability of the households to meet their basic needs, such as food consumption, education, and health. This lead to deteriorating health conditions, causes anxiety and discomfort; furthermore, this can affect a person's quality of life (Do \& Bautista 2015).

\section{CONCLUSION}

Most subjects classified as having a body mass index (BMI) $>25 \mathrm{~kg} / \mathrm{m}^{2}$ (obese). The prevalence of anemia in this study was $28.5 \%$, with an average hemoglobin level of $12.6 \mathrm{~g} /$ dl. The most common infectious and noncommunicable diseases suffered by the subject are Acute Respiratory Infection (ARI) and joint pain. Most subjects suffered pain in the past four weeks. Most subjects had a relatively good quality of life, with an average score of $76.3 \pm 13.3$. There is a positive relationship between the number of family members with physical role dimensions and Physical Component Summary (PCS). There is no significant relationship between nutritional status and anemia status with quality of life. There is a positive relationship between ARI with dimensions of social function and joint pain with the role of emotions. There is a positive relationship between the health conditions of the past four weeks with dimensions of physical roles, general health, vitality/energy, mental health, PCS, and MCS. Factors that influence the quality of life of the subject are the family size and total household expenditure.

\section{ACKNOWLEDGEMENT}

The authors would like to thank to Neysvan Hoogstraten Foundation (IN 269) and the Indonesia Endowment Fund for Education (LPDP-Lembaga Pengelola Dana Pendidikan) for funding this research; and also to the Nusantara Plantation Company VIII (PTPN VIIIPerusahaan Terbatas Perkebunan Nusantara), Pangalengan, for permitting us to conduct this research at their place.

\section{AUTHOR DISCLOSURES}

The authors have no conflict of interest.

\section{REFERENCES}

Agung IGAA. 2008. Pengaruh perbaikan gizi kesehatan terhadap produktivitas kerja. Piramida 4(1):1-15.

Al-Aboudi IS, Hassali MA, Shafie AA, Hassan A, Alrasheedy AA. 2015. A cross-sectional assessment of health-related quality of life among type 2 diabetes patients in Riyadh, Saudi Arabia. SAGE Open Medicine 25(3):127-135. https://doi. org/10.1177/2050312115610129.

[Balitbangkes] Badan Penelitian dan PengembanganKesehatan. RisetKesehatan Dasar 2013. Jakarta (ID): Kemekes RI.

Beck KL, Conlon CA, Kruger R, Heath ALM, Matthys C, Coad J, Stonehouse W. 2012. Iron status and self-perceived health, wellbeing, and fatigue in female university students living in New Zealand. J Amer Coll Nutr 31(1):45-53. https://doi.org/10. 1080/07315724.2012.10720008.

Bjorner JB, Wolden ML, Gundgaard J, Miller KA. 2013. Benchmarks for interpretation of score differences on the SF-36 health survey for patients with diabetes. Value in Health 16(6):993-1000. https://doi. org/10.1016/j.jval.2013.06.022.

[BPPK Depkes RI] Badan Penelitian dan Pengembangan Kesehatan Departemen 
Kesehatan RI. 2008. Laporan Hasil Riset Kesehatan Dasar (Riskesdas).

Brown WJ, Mishra G, Kenardy J, Dobson A. 2000. Relationships between body mass index and well-being in young Australian women. Intl J Obes 24(10):1360-1368. https://doi.org/10.1038/sj.ijo.0801384.

Cella DD, Breitbart W. 2001. Cancer related fatigue: Prevalence of proposed diagnostic criteria in a United States sample of cancer survivors. J Clin Oncol 19(14):3385-3391.

De Zwaan M, Petersen I, Kaerber M, Burgmer R, Nolting B, Legenbauer T, Benecke A, Harpertz S. 2009. Obesity and quality of life: a controlled study of normal-weight and obese individuals. Psychosomatics 50(5):474-482. https://doi.org/10.1016/ S0033-3182(09)70840-0.

Do YK, Bautista MA. 2015. Tobacco use and household expenditures on food, education, and healthcare in low- and middleincome countries: A multilevel analysis. BMC Public Health. 15(1098):1-11. doi:10.1186/s12889-015-2423-9.

Efficace F, Mandelli F, Fazi P, Santoro C, Gaidano G, Cottone F,Borchiellini A, Carpenedo M, Simula MP, Giacomo VD, et al. 2016. Health-related quality of life and burden of fatigue in patients with primary immune thrombocytopenia by phase of disease. Am J Hematol 91(10):995-1001. https:// doi.org/10.1002/ajh.24463.

Erwin PP, Karmini NL. 2012. Pengaruh pendapatan, jumlah anggota keluarga, dan pendidikan terhadap pola konsumsi rumah tangga miskin di Kecamatan Gianyar. E-Jurnal Ekonomi Pembangunan Universitas Udayana 1(1):39-48.

Fayers PM, Machin D. 2007. Quality of Life: The Assessment, Analysis, and Interpretation of Patient-Reported Outcomes. 2nd ed. England (UK): John Wiley \& Sons Ltd.

Fitriyani Y, Roosita K, Hartati Y, Effendi YH. 2008. Kondisi lingkungan, perilaku hidup sehat, dan status kesehatan keluarga wanita pemetik teh. J Gizi Pangan 3(2):86-93. doi: https://doi.org/10.25182/jgp.2008.3.2.8693.

Flechtner H, Bottomley A. 2003. Fatigue and quality of life: Lessons from the real world. The Oncologist 8(Supplement 1):5-9.

Haas JD, Brownlie T. 2001. Iron deficiency and reduced work capacity: A critical review of the research to determine a causal relationship. J Nutr 131(2):676S-690S. https://doi.org/10.1093/jn/131.2.676S.

Huang IC, Frangakis C, Wu AW. 2006. The relationship of excess body weight and health-related quality of life: Evidence from a population study in Taiwan. Intl $\mathrm{J}$ Obes 30(8):1250-1259. doi: https://doi. org/10.1038/sj.ijo.0803250

Kundu S, Prasad SK, Maji B, Ray D, Syamal AK, Mukherjee S. 2013. Nutritional status and productivity of female tea pluckers of a tea garden in Dooars, West Bengal. Int J Biol Med Res. 4(2): 3101 - 3106.

Kusumawati Y. 2012. Peran ganda perempuan pemetik teh. Komunitas: International Journal of Indonesian Society and Culture 4(2):157-167. doi: https://doi. org/10.15294/komunitas.v4i2.2411.

Lemeshow S, Hosmer DW, Klar J, Lwanga SK. 1997. Adequacy of Sample Size in Health Studies. Edisi terjemahan. Yogyakarta (ID): Gadjah Mada University Press.

Leslie W, Hankey C. 2015. Aging, nutritional status and health. Healthcare 3(3):648-658. doi:10.3390/healthcare3030648.

Linder JA, Singer DE. 2003. Health-related quality of life of adults with upper respiratory tract infections. $\mathrm{J}$ Gen Internal Med 18(10):802-807. https://doi. org/10.1046/j.1525-1497.2003.21246.x.

Locatelli F, Del Vecchio L. 2014. Haemoglobin levels and health-related quality of life: A neglected hard end point. Nephrol Dial Transplant 29(7):1272-1274. https://doi. org/10.1093/ndt/gfu059.

Loonen HJ, Derkx BH, Otley AR. 2001. Measuring health-related quality of life of pediatric patients. J Pediatr Gastroenterol Nutr 32(5):523-526.

[MoHRI] Ministry of Health Republic Indonesia. 2013. Pedoman pemenuhan Kecukupan Gizi Pekerja selama Bekerja. Jakarta (ID): Kementrian Kesehatan RI.

Mahardikawati VA, Roosita K. 2008. Aktivitas fisik, asupan energi dan status gizi wanita pemetik teh di PTPN VIII Bandung, Jawa Barat.JGiziPangan3(2):79-85.doi:https:// doi.org/10.25182/jgp.2008.3.2.79-85.

McPhee JS, French DP, Jackson D, Nazroo J, Pendleton N, Degens H. 2016. Physical activity in older age: Perspectives for 
healthy ageing and frailty. Biogerontology 17(3):567-580. doi:10.1007/s10522-0169641-0.

Niswah I, Damanik MRM, Ekawidyani KR. 2014. Kebiasaan sarapan, status gizi, dan kualitas hidup remaja SMP Bosowa Bina Insani Bogor. J Gizi Pangan 9(2):97-102. doi: https://doi. org/10.25182/jgp.2014.9.2.\%25p.

Pearson JM, Schlettwein-Gsell D, Brzozowska A, Staveren WAV, Bjornsbo K. 2001. Life style characteristics associated with nutritional risk in elderly subjects aged 80-85 years. J Nutr Health Aging 5(4):278-283.

Pradono J, Sulistyowati N. 2014. Hubungan antara tingkat pendidikan, pengetahuan tentang kesehatan lingkungan, perilaku hidup sehat dengan status kesehatan studi korelasi pada penduduk umur 10-24 tahun di Jakarta Pusat. Buletin Penelitian Sistem Kesehatan 17(1):89-95.

Rachmawati Y, Perwitasari DA, Adnan A. 2014. Validasi kuesioner SF-36 versi Indonesia terhadap pasien hipertensi di puskesmas Yogyakarta. Jurnal Pharmacy 11(1):14-25. doi: 10.30595/pji.v11i1.845.

RAND. 2009. Scoring Instructions for the 36Item Short Form Survey (SF-36). http:// www.rand.org/health/surveys tools/ mos/mos core 36 item scoring.htm 1 . [Accessed 2nd April 2016].

Santos FAAS, Sousa LDP, Serra MAADO, Rocha FAC. 2016. Factors that influence the quality of life of community health workers. Acta Paul Enferm 29(2):191-197. doi: $\quad$ http://dx.doi.org/10.1590/19820194201600027.

Semba RD, Kalm LM, de Pee S, Ricks MO, Sari M, Bloem MW. 2008. Paternal smoking is associated with increased risk of child malnutrition among poor urban families in Indonesia. Public Health Nutr 10(1):7-15. doi: https://doi.org/10.1017/ S136898000722292X.

Sulistyowati HN, Sinaga BM, Novindra N. 2017. Impacts of government and household expenditure on human development index. Jurnal Ekonomi dan Kebijakan. 10(2): 412-428. doi:http://dx.doi.org/10.15294/ jejak.v10i2.11305.

Ul-Haq Z, Mackay DF, Fenwick E, Pell JP. 2012. Impact of comorbidity on the association between body mass index and healthrelated quality of life: A Scotland-wide crosssectional study of 5,608 participants. BMC Public Health 12(1):143. https://doi. org/10.1186/1471-2458-12-143.

Wanden-Berghe C, Sanz-Valero J, Escribà-Agüir V, Castelló-Botia I, Guardiola-WandenBerghe R. 2009. Evaluation of quality of life related to nutritional status. $\mathrm{Br} \mathrm{J}$ Nutr 101(07):950-960. doi: https://doi. org/10.1017/S0007114508207178.

Wee HL, Wu Y, Thumboo J, Lee J, Tai ES. 2010. Association of body mass index with ShortForm 36 physical and mental component summary scores in a multiethnic Asian population. Intl J Obes 34(6):1034-1043. https://doi.org/10.1038/ijo.2010.24.

[WHO] World Health Organization. 2008. Worldwide Prevalence of Anemia 19932005: WHO Global database on anaemia. Geneva $(\mathrm{CH})$ : World Health Organization.

Zubaran C, Persch K, Tarso D, Ioppi A, Mezzich J. 2008. The correlation between health status and quality of life in southern Brazil. Sao Paulo Med J 126(5):257-261. https://doi. org/10.1590/S1516-31802008000500003. 